TARNOWSKIE STUDIA TEOLOGICZNE 35 (2016) NR 2, S. 109-123

http://dx.doi.org/10.15633/tst.2108

ks. Piotr Jaworski ${ }^{1}$

TARNÓW

\title{
Biskupi czasów przedrozbiorowych w świetle propagandy antykościelnej prowadzonej przez władze polityczne Polskiej Rzeczpospolitej Ludowej ${ }^{2}$ w latach 1944-1989
}

\section{Krótka geneza problemu}

Jednym z podstawowych ideologicznych celów komunistów, przejmujących po zakończeniu II wojny światowej władzę w Polsce, była - wzorem Związku Socjalistycznych Republik Radzieckich (ZSRR) - walka z religią. Cel ten wynikał z przyjętej ideologii marksistowsko-leninowskiej opartej na „materializmie dialektycznym i historycznym"3 - odrzucającej istnienie Boga. Ten punkt widzenia miał swe źródło w twierdzeniu Karola Marksa, który religię

1 Piotr Jaworski - ksiądz katolicki, absolwent Papieskiej Akademii Teologicznej w Krakowie Wydział Teologiczny Sekcja w Tarnowie (2005), obecnie wikariusz w parafii Najświętszego Serca Pana Jezusa w Tarnowie.

2 Autor artykułu w celu uniknięcia chaosu interpretacyjnego stosuje dla lat 1944-1989 nazwę Polska Rzeczpospolita Ludowa (PRL), mimo że taką nazwę państwo polskie przyjęło dopiero na mocy konstytucji lipcowej z 1952 roku.

3 Materializm dialektyczny - kierunek filozoficzny zapoczątkowany w II poł. xıx wieku przez Karola Marksa i Fryderyka Engelsa. Podstawą materializmu dialektycznego jest przyjęcie, że cała realna rzeczywistość jest materialna i nie ma żadnego obiektywnie istniejącego bytu, którego nie dałoby się sprowadzić do jego materialnej podstawy. Zob. szerzej: J. Ładosz, S. Kozyr-Kowalski, Dialektyka a społeczeństwo, Warszawa 1972; J. Ładosz, Materializm dialektyczny, Warszawa 1973.

Materializm historyczny - marksistowska teoria, będąca zastosowaniem materializmu dialektycznego na obszarze historii i nauk społecznych. Według materializmu historycznego stosunki ludzi w procesie produkcji są stosunkami podstawowymi i pierwotnymi, określającymi wszystkie inne stosunki społeczne, a mianowicie: stosunki polityczne i ideologiczne. Zob szerzej: A. Spirkin, Zarys filozofii marksistowskiej (tytuł oryg.: Kurs marksistskoj fiłosofii), tł. L. Smolińska, Warszawa 1968. 
określał jako „opium ludu”, czyli coś urojonego, dającego ułudę szczęścia i przeszkadzającego w osiągnięciu szczęścia realnego, prawdziwego - stąd wyprowadzony został postulat zniesienia, usunięcia religii z przestrzeni ludzkiego życia. Nic więc dziwnego, że władze polityczne, działając na takiej podbudowie ideologicznej, wobec powszechnej religijności społeczeństwa, traktowały Kościół jako konkurenta, osłabiającego autorytet władzy. Z tego powodu obóz rządzący PRL w latach 1944-1989, z różnym nasileniem stosował wobec Kościoła politykę represji i deprecjonowania ${ }^{4}$.

Istotnym elementem tego programu stała się propaganda antykościelna obejmująca różnorodne aspekty życia i funkcjonowania Kościoła. Jak zauważył ks. prof. Jerzy Myszor: „obok terroru propaganda stała się najważniejszym środkiem przechwycenia i umacniania władzy w państwach totalitarnych"s.

Propaganda Polskiej Zjednoczonej Partii Robotniczej (PZPR) traktowała księży biskupów jako wykonawców antypolskiej polityki papiestwa ${ }^{6}$. W tym kontekście biskupi byli traktowani jako element antypaństwowy i anty-

4 Represje wobec osób duchownych są przedstawione w: Leksykon duchowieństwa represjonowanego w PRL w latach 1945-1989, red. J. Myszor, t. 1-3, Warszawa 2002-2006; Represje wobec osób duchownych i konsekrowanych w PRL w latach 1944-1989, red. A. Grześkowiak, Lublin 2004. Zob. Represje wobec Kościoła w krajach bloku wschodniego. Komuniści przeciw religii po 1944 r., red. J. Marecki, Kraków 2011.

Przykładem obojętnej, a czasem wręcz wrogiej postawy rządzących wobec Kościoła, była chociażby kwestia administracji apostolskich na tzw. Ziemiach Odzyskanych. Decyzją prymasa Polski powołano 5 administratorów apostolskich na tzw. ziemiach poniemieckich, co miało tymczasowo uregulować sprawy administracji kościelnej do momentu ostatecznego określenia kwestii granicznych i związanej z tym sprawy utworzenia na tych terenach diecezji. Jednak rządzący nie respektowali tej decyzji, traktując administratorów jak zwykłych księży. Zob. J. Żaryn, Kościół a władza w Polsce (1945-1950), Warszawa 1997, s. 53. Należy zauważyć, że Kościół katolicki pozostawał najważniejszym wrogiem państwa rządzonego przez komunistów co najmniej do sierpnia 1980 roku. Zob. szerzej: A. Dudek, R. Gryz, Komuniści i Kościót $w$ Polsce (1945-1989), Kraków 2006, s. 373-426, przy czym wg prof. J. Żaryna lata 1945-1955 były najtrudniejszą dekadą dla Kościoła katolickiego. Zob. J. Żaryn, Kościół w PRL, Warszawa 2002, s. 11-14. Antykościelnej polityce i represjom wobec Kościoła służyły specjalnie tworzone komórki i agendy rządowe. Zob. B. Noszczak, Polityka państwa wobec Kościoła rzymskokatolickiego w Polsce w okresie internowania prymasa Stefana Wyszyńskiego 1953-1956, Warszawa 2008.

5 J. Myszor, Pozostała tylko ambona, w: Przez Morze Czerwone. Kościót w Polsce pod rządami komunistów. Propaganda antykościelna. Dodatek specjalny do „Gościa Niedzielnego”, red. A. Dziurok, A. Grajewski, Warszawa 2009, s. 2.

6 Zob. B.M., Z historii antypolskiej polityki papiestwa. 1. Mieczem i zdrada, „Żołnierz Wolności” 4 (1953) nr 236, s. 4. (B.M. to inicjały, jakimi podpisał się autor artykułu). 
narodowy. Powodowało to, że władze partyjno-państwowe nader chętnie inspirowały powstawanie artykułów oraz innych form wydawniczych w celu dyskredytacji poszczególnych księży biskupów. Stąd już w roku 1950 powstała praca autorstwa Andrzeja Nowickiego 1000 lat zatargów z papieżami, która stała się swoistą wskazówką dla antykościelnych propagandystów ze względu na stwierdzenie, „że od tysiąca lat - po dziś dzień działa na terenie Polski szeroko rozgałęziona bogata i potężna agentura papieska, którą papież stawiał dawniej do dyspozycji Habsburgom, zaborcom, okupantom, a dziś stara się przekształcić w narzędzie antypolskiej działalności”’.

Ataki prasowe wymierzone w Kościół, które na dobre rozpoczęły się po roku 1948, stały się nieodzownym elementem programu wspierania laicyzacji życia społecznego prowadzonego przez władze partyjno-państwowe ${ }^{8}$. Do tego celu były wykorzystywane łamy różnorodnych czasopism i gazet codziennych ${ }^{9}$, w których zamieszczano artykuły podważające zaufanie do hierarchii kościelnej i samego Kościoła. Przykładem ilustrującym ten stan rzeczy jest artykuł opublikowany w gazecie codziennej Wojska Polskiego „Żołnierz Wolności”, przedstawiający, stopień wykształcenia biskupów, w którym to zamieszczono informację, że w końcu x wieku większość biskupów nie umiała wymienić wszystkich liter alfabetu, ponieważ znali tylko niektóre $\mathrm{z}$ nich ${ }^{10}$.

W ślad za podobnymi do tej informacjami szły wyolbrzymione doniesienia o zdarzeniach będących świadectwem słabości ludzkich, takich jak pijaństwo itd. ." . Materiały te ukierunkowane na dyskredytowanie biskupów ukazywały się także na łamach innych czasopism, takich jak np. „Sztandar Wolności” czy „Panorama”.

7 A. Nowicki, 1000 lat zatargów z papieżami, Warszawa 1950, s. 156.

${ }^{8}$ Zob. Ł. Marek, M. Bortlik-Dźwierzyńska, Za Marksem bez Boga. Laicyzacja życia społecznego w Polsce w latach 1945-1989, Katowice 2014.

9 Zob. M. Mazur, Propagandowy obraz świata. Polityczne kampanie prasowe w PRL 19561980. Model analityczno-koncepcyjny, Warszawa 2003.

${ }^{10}$ Zob. I. Frąckowiak, Benedyktynka, Karol Wielki i znajomość alfabetu, „Żołnierz Wolności” 11 (1960) nr 111, s. 4.

${ }^{11}$ Zob. D.Z., Królowie i hierarchowie (2), „Żołnierz Wolności” 36 (1985) nr 145, s. 4.

${ }_{12}$ Zob. W. Wanat, A Polska nie stuchała, „Sztandar Ludu” 13-14 sierpnia 1966, s. 1; D.K., Wertując karty historii „Panorama” 16 (1966), s. 1. Należy również zauważyć, że komunistyczną propagandę wspomagała cenzura. Każdy artykuł przed drukiem musiał być zatwierdzony przez wojewódzki oddział Głównego Urzędu Kontroli Prasy, Publikacji i Widowisk. 
Akcja dyskredytacji biskupów była przemyślanym działaniem, wymierzonym przeciw całemu episkopatowi, mającym na celu stworzenie negatywnego wizerunku hierarchów. Stąd też w prowadzonych działaniach starano się przedstawiać ich przede wszystkim w negatywnym świetle, a jeśli pisano o nich pozytywnie, to tylko dla kontrastu z innymi „antypolskimi” hierarchami.

\section{Pozytywne wypowiedzi na temat poszczególnych biskupów}

Grupę hierarchów zasługujących na akceptację według propagandzistów otwiera arcybiskup gnieźnieński Borzysław (1314-1317), który w broszurce wydanej przez Towarzystwo Krzewienia Kultury Świeckiej przedstawiony jest jako hierarcha wspierający proces zjednoczenia Polski w okresie rozbicia dzielnicowego. Jego pozytywna działalność miała - w myśl założeń propagandy antykościelnej - kontrastować z sugerowaną antypaństwową postawą innych biskupów ${ }^{13}$.

Kolejnym w tym swoistym zestawieniu, zasługującym na akceptację hierarchą, był arcybiskup lwowski Grzegorz z Sanoka (1406-1477), uznawany przez propagandystów za postać postępową, aczkolwiek w jego przypadku przemilczano fakt bycia arcybiskupem ${ }^{14}$. W wydawanych w latach pięćdziesiątych książeczkach autorstwa Andrzeja Nowickiego ukazywano Grzegorza z Sanoka jako prekursora materializmu ${ }^{15}$. Tenże autor w 1959 i 1961 roku w „Biuletynie Informacyjnym” przeznaczonym do wyłącznego użytku generałów i oficerów zaliczył go do przedstawicieli racjonalizmu, walczących o kulturę świecką w Polsce ${ }^{16}$, a tym samym za pierwszego materialistę. Oficjalne uznanie Grzegorza z Sanoka przez wspomnianego autora za pierwszego materialistę nastąpiło jednak dopiero w 1980 roku wraz z konstatacją,

${ }_{13}$ Zob. Historyczne tło i aktualny stan stosunków między państwem a Kościołem, Warszawa 1984, s. 11.

${ }^{14}$ Zob. M. Kęsek, Wizerunek Kościoła Katolickiego w Polsce do 1945 r. na łamach „Żołnierza Wolności” w latach 1950-1990, Kraków 2005, mps, s. 87-88.

${ }_{15}$ Zob. A. Nowicki, Grzegorz z Sanoka 1406-1477, Warszawa 1958; A. Nowicki, Program walki o kulturę racjonalistyczną i moralność opartą na podstawach racjonalistycznych, Kraków 1957, s. 19.

${ }^{16}$ Zob. A. Nowicki, Ateizm w Polsce i jego aktualne potrzeby, „Biuletyn Informacyjny” (Wyd. Zarząd Propagandy i Agitacji GZP) 1959 nr 16, s. 11. 
że początki polskiej filozofii materialistycznej sięgają połowy xv wieku ${ }^{17}$. Tak skonstruowana konkluzja pozwoliła na ukazanie w 1987 roku w „Żołnierzu Wolności” Grzegorza z Sanoka jako znakomitego matematyka i filozofa, wykazującego sprzeczność między wiarą a rozumem ${ }^{18}$, co było oczywiście tezą absurdalną.

W powyższych wydawnictwach propagandowych nie poinformowano czytelników, że wobec niezachowania się podstawowej spuścizny pisarskiej, głównym źródłem poznania poglądów społeczno-politycznych i filozoficznych Grzegorza z Sanoka jest jego biografia autorstwa Kallimacha Vita et mores Gregorii Sanocei oraz wcześniejszy o 4 lata list dedykacyjny, poprzedzający księgę Fannietum. W kwestii relacji Kallimacha zawartej w Vita et mores Gregorii Sanocei istnieją opinie, że nie jest ona w pełni wiarygodna ${ }^{19}$. W 1980 roku Stanisław Cynarski, podsumowując stan badań na powyższy temat, stwierdził, że Kallimach w Vita et mores Gregorii Sanocei przedstawił własne poglądy, a nie opisywanego arcybiskupa ${ }^{20}$. Odmienne zdanie prezentował w 2000 roku Krzysztof Baczkowski, który uznał, że Kallimach nie mógł zbyt jaskrawo mijać się z rzeczywistością, w sytuacji gdy żył jeszcze bohater jego opowiadania, a także wiele osób znających osobiście tego arcybiskupa, mających możliwość zweryfikowania prawdziwości informacji podanych przez tego humanistę, niedbającego zresztą o rzetelne opisanie wydarzeń, dat, a nawet nazw ${ }^{21}$. Jednak to, że dostępne źródła milczą o ewentualnych protestach odnośnie do tekstu w Vita et mores Gregorii Sanocei, nie może przesądzać, że takowych nie było. Zatem jak stwierdził Stanisław Cynarski, spór o poglądy Grzegorza z Sanoka jest nadal aktualny. Jedynie dla propagandzistów partyjnych ten arcybiskup był bezspornie materialistą ${ }^{22}$.

${ }_{17}$ Zob. A. Nowicki, Filozofia kultury Grzegorza $z$ Sanoka, „Rocznik Sanocki” 5 (1980), s. 98.

18 Zob. D. Brodziński, Nasze konsultacje. Tolerancja religijna, „Żołnierz Wolności” 38 (1987) nr 146 , s. 4 .

19 Zob. I. Zarębski, Grzegorz z Sanoka (ok. 1407-1477) arcybiskup lwowski, prozaik i poeta, Kraków 1960, s. 89.

${ }^{20}$ Zob. S. Cynarski, Stan badań nad Grzegorzem z Sanoka, „Rocznik Sanocki” 5 (1980), s. $37-38$.

${ }^{21}$ Zob. K. Baczkowski, Wartość źródłowa prac historyczno-literackich Filipa Kallimacha, w: Nihil superfluum esse. Prace z dziejów średniowiecza ofiarowane profesor Jadwidze Krzyżaniakowej, Poznań 200o, s. 477.

${ }^{22}$ W 1980 roku Andrzej Nowicki dzięki postaci Grzegorza z Sanoka (traktowanego jako materialista) ustalił początki polskiej filozofii materialistycznej na połowę xv wieku. Zob. M. Kęsek, Wizerunek Kościoła Katolickiego w Polsce..., s. 88. 
Wśród hierarchów mających uznanie, a tym samym zaliczonych do grona postaci pozytywnych, znajdował się arcybiskup Jan Łaski (1456-1531). Wiązało się to z jego dokonaniami jako kanclerza wielkiego koronnego, sekretarza królewskiego, działacza ruchu egzekucyjnego i kodyfikator prawa zawartego w tzw. Statucie Łaskiego. Obdarzony (mimo braku wyksztalcenia wyższego) talentem politycznym, arcybiskup Łaski był idealnym przeciwstawieniem, w zamyśle propagandy w 1966 roku, w stosunku do biskupów polskich - autorów Orędzia biskupów polskich do biskupów niemieckich ${ }^{23}$. Zdaniem propagandy polscy biskupi, autorzy Orędzia, takiego talentu jak arcybiskup Łaski nie posiadali. To twierdzenie było upowszechniane m.in. na łamach „Żołnierza Wolności” ${ }^{24}$. W 1985 roku na łamach wspomnianego czasopisma nawiązując do postaci arcybiskupa, przytoczono opinię Andrzeja Modrzewskiego, który wspominał go jako „najoświeceńszego i najmędrszego księcia Kościoła i Rzeczypospolitej”" ${ }^{25}$. Te i inne oceny prymasa Łaskiego były zgodne z naukowymi opracowaniami m.in. Włodzimierza Dworzaczka i Władysława Konopczyńskiego ${ }^{26}$.

\section{Wybrane przykłady negatywnych wypowiedzi na temat episkopatu Polski i niektórych księży biskupów}

Grupę hierarchów negatywnych, według propagandzistów, otwiera arcybiskup gnieźnieński Henryk Kietlicz (1199-1219), który był postrzegany jako przedstawiciel prowadzonej przez papiestwo na przestrzeni dziejów polityki antypolskiej. Ten sposób widzenia postaci arcybiskupa znalazł swe odzwierciedlenie w wydanej w 1949 roku przez Andrzeja Nowickiego książce noszącej tytuł: Papieże przeciw Polsce, w której to wymienił arcybiskupa Kietlicza jako wykonawcę antypolskiej polityki papiestwa ${ }^{27}$.

${ }^{23}$ Zob. M. Kęsek, Wizerunek Kościoła Katolickiego w Polsce..., s. 88.

${ }^{24}$ Zob. A.B., Co, kto, gdzie?, „Żołnierz Wolności” 17 (1966) nr 66, s. 4.

${ }^{25}$ E. Szmigielska, Frycz Modrzewski, czyli o odwadze mądrości, „Żołnierz Wolności” 36 (1985) nr 184, s. 4.

${ }^{26}$ W. Dworzaczek, Łaski Jan h. Korab (1456-1531), kanclerz w. kor., prymas Polski polityk i kodyfikator prawa, Kraków 1973, s. 236; W. Konopczyński, Dzieje Polski nowożytnej, t. 1, Warszawa 1986, s. 77.

${ }_{27}$ Zob. A. Nowicki, Papieże przeciw Polsce, Warszawa 1949, s. 18-19. 
W 1952 roku Zespół Propagandowo-Szkoleniowy Centralnego Komitetu Stronnictwa Demokratycznego w wydanej przez siebie broszurce negatywnie ocenił działalność tego arcybiskupa ${ }^{28}$. Informacje o jego antypolskiej działalności wiązały się przede wszystkim z próbami zjednoczenia Polski i oporem stawianym tym próbom przez część możnowładców i wyższego duchowieństwa, przy czym koronnym argumentem jest tu konflikt między arcybiskupem a księciem Władysławem Laskonogim na kanwie projektu arcybiskupa, zmierzającego do uwolnienia Kościoła spod władzy świeckiej. Dążenia te nie mogły być jednak spełnione, w wyniku czego w 1206 roku arcybiskup rzucił klątwę na księcia. Jednakże Władysław nie ugiął się i wygnał Kietlicza z Wielkopolskii ${ }^{29}$. Mógł to zrobić, gdyż poparła go część duchowieństwa, $\mathrm{z}$ biskupem poznańskim Arnoldem i kanclerzem Wincentym na czele. Szerszą informację na ten temat podano w roku $1953 \mathrm{w}$ „Żołnierzu Wolności”, przy czym podana informacja podnosiła fakt, że arcybiskup Kietlicz na polecenie papieża Innocentego III walczył z księciem Władysławem Laskonogim dążącym do zjednoczenia Polski. Wspomniany książę, wedle tej publikacji, został wyklęty za to, że ośmielił się przeciwstawić dążeniu papieskiej agentury do władzy w Polsce ${ }^{30}$. Ten punkt widzenia znalazł swe miejsce w wydanych w 1961 roku materiałach do szkolenia politycznego w wojsku, według którego arcybiskup Kietlicz był antypaństwowym spiskowcem ${ }^{31}$.

W podobnym klimacie przedstawiano Jana Muskatę, biskupa krakowskiego w latach 1294-1320, który dla propagandy antykościelnej był przykładem hierarchy prowadzącego działalność polityczną, sprzeczną z interesem narodu ${ }^{32}$. Stąd już w 1950 roku został negatywnie przedstawiony w broszurce przeznaczonej dla agitatorów, wydanej przez Wydział Propagandy Komitetu Centralnego (KC) PZPR $^{33}$. Z kolei w 1966 roku określono biskupa Muskatę jako zwolennika panowania niemieckiego w Polsce. Taką informację podała Irena Koberdowa w materiałach lektorskich do szkolenia politycznego

${ }^{28}$ Zob. S. Idzior, Państwo a Kościót, Warszawa 1952, s. 13.

${ }_{29}$ Zob. M. Kęsek, Wizerunek Kościoła Katolickiego w Polsce..., s. 73-74 i 119.

${ }^{30}$ Zob. B.M., Z historii antypolskiej polityki papiestwa..., s. 4.

${ }^{31}$ Zob. Zagadnienia światopoglądowe. „Materiały $n r 3$ do szkolenia politycznego podoficerów zawodowych", Warszawa 1961, s. 106.

${ }^{32}$ Zob. M. Kęsek, Wizerunek Kościoła Katolickiego w Polsce..., s. 77.

${ }_{33}$ Zob. Polska Ludowa a Kościół katolicki, „Notatnik Agitatora” marzec 1950 [numer dodatkowy], s. 108. 
w wojsku ${ }^{34}$. Działalność germanizacyjną zarzucano temu biskupowi także w 1968 roku w wojskowych materiałach szkoleniowych. Działalność ta, miała polegać na sprowadzaniu do Polski niemieckich zakonów oraz prowadzeniu walki przez biskupa $z$ dążącym do zjednoczenia Polski Władysławem Łokietkiem $^{35}$.

Kolejną postacią w grupie negatywnie przedstawianych członków episkopatu jest biskup warmiński Jan Dantyszek (1485-1548), który - w myśl podanej w 1953 roku informacji na łamach „Żołnierza Wolności” - miał wysłać do Fromborka swojego dworaka $\mathrm{z}$ nakazem wypędzenia przebywających u Mikołaja Kopernika niemieckiego uczonego Jerzego Joachima Retyka ${ }^{36}$ i reformatora luterańskiego Aleksandra Skulteta ${ }^{37}$. Powodem była obawa, że ich pobyt może świadczyć o tolerowaniu herezji w diecezji, co to mogłoby zaszkodzić biskupowi w uzyskaniu godności kardynalskiej ${ }^{38}$. O tym fakcie pisał w 1873 roku ks. Ignacy Polkowski w biografii astronoma, gdzie informował o liście Dantyszka do biskupa chełmińskiego, w którym Dantyszek prosił go, aby przekonał Kopernika do zerwania przyjaźni ze Skultetem ${ }^{39}$. Informacja ta posłużyła w 1973 roku do stwierdzenia na łamach „Żołnierza Wolności”, że biskup Dantyszek był wrogiem Kopernika ${ }^{40}$. Przedstawione wiadomości, jakkolwiek sprzeczne z naukową biografią biskupa Dantyszka, autorstwa wybitnego znawcy epoki zygmuntowskiej Władysława Pociechy ${ }^{41}$,

${ }^{34}$ I. Koberdowa, Polityczna rola Kościoła katolickiego $w$ tysiącleciu Polski, „Biuletyn Informacyjny” (Wyd. Zarząd Propagandy Głównego Zarządu Politycznego Wojska Polskiego) 1966 nr 12 (308), s. 7.

${ }^{35}$ Zob. S. Królik, Laicyzacja życia społecznego w Polsce, w: Społeczeństwo - kultura - technika. Materiały nr 5 dla kierowników grup do zajęć politycznych z elewami szkół podoficerskich, żotnierzami i podoficerami służby zasadniczej, Warszawa 1968, s. 139.

${ }^{36}$ Właściwie - Georg Joachim Iserin, używał też nazwiska matki de Porris i jego niemieckiego tłumaczenia von Lauchen, stąd Georg Joachim von Lauchen. Najbardziej znany jednak z przybranego nazwiska Retyk (łac. Rheticus).

37 Aleksander Skultet (właściwie: Sculteti) (zm. w 1564). Jeden z wybitniejszych postaci polskiego odrodzenia, autor kroniki prusko-warmińskiej Chronicon vel Catalogus rerum Pruthenicarum et praesertim Varmiensium.

${ }^{38}$ Zob. J. Czuliński, Tam rodziła się Kopernikowska prawda o wszechświecie, „Żołnierz Wolności” 4 (1953) nr 146, s. 4.

39 Zob. I. Polkowski, Żywot Mikołaja Kopernika, Gniezno 1873, s. 223.

${ }^{40}$ Zob. A. Czermiński, W epoce Kopernika, jego współcześni, „Żołnierz Wolności” 24 (1973) nr 221, s. 4.

${ }^{41}$ Zob. W. Pociecha, Dantyszek (von Hofen Flachsbinder) Jan (1485-1548), w: Polski słownik biograficzny, t. 4, Kraków 1938, s. 424-430. 
zawierają $\mathrm{w}$ części prawdę związaną z rzeczywistym pogorszeniem stosunków między Kopernikiem a biskupem Dantyszkiem w latach 1538-1539.

Interesującą postacią w grupie biskupów był Stanisław Hozjusz, przedstawiany przez propagandę PRL-u jako osoba nietolerancyjna ${ }^{42}$. W 1966 roku w broszurce propagandowej wydanej przez Centralny Ośrodek Doskonalenia Kadr Laickich został uznany za osobę sprzeciwiającą się nowym prądom $\mathrm{w}$ nauce, religii i kulturze ${ }^{43}$. W następnych latach postać biskupa gościła wielokrotnie na łamach „Żołnierza Wolności”, będącego jednym z najbardziej wpływowych pism ówczesnej propagandy ${ }^{44}$. W 1985 roku podano wiadomość o tym purpuracie jako prześladowcy Andrzeja Frycza Modrzewskiego, którego dzieło O poprawie Rzeczypospolitej, zdaniem Hozjusza, „grzeszyło nie tylko przeciw religii, ale i przeciw Ojczyźnie" ${ }^{45}$. W 1987 roku podano w „Żołnierzu Wolności” informację, że kardynał Hozjusz czynił wszystko, by nie dopuścić do uchwalenia konfederacji warszawskiej 1573 roku, a potem do jej ratyfikacji przez króla. Pochwalał też represje inkwizycyjne jako skuteczny środek walki z herezją, a rzeź nocy św. Bartłomieja uważał za dobrodziejstwo, którym Bóg obdarzył Francję, błagając jednocześnie, aby podobne dobrodziejstwo zechciał zesłać i Polsce ${ }^{46}$.

Kolejnym hierarchą zajmującym szczególną pozycję w tym swoistym panteonie był biskup krakowski Piotr Gembicki (1585-1657), postrzegany jako przeciwnik postępu, wolności i uwłaszczenia chłopów. Według ówczesnej propagandy biskup Gembicki bezlitośnie rozprawiał się z wszelkimi przejawami buntu podhalańskich chłopów przeciwko swym ciemiężycielom, który wywołał Aleksander Leon Kostka-Napierski. Takie widzenie postaci biskupa w kontekście stłumienia przez niego buntu chłopów na Podhalu zaprezentował Władysław Bortnowski w 1951 roku na łamach „Żołnierza Wolności” z okazji 30o. rocznicy powstania Kostki-Napierskiego ${ }^{47}$. Wtórował mu Juliusz Bardach, który na łamach miesięcznika ideologicznego, organu

${ }^{42}$ Por. M. Kęsek, Wizerunek Kościoła Katolickiego w Polsce..., s. 83-85.

${ }_{43}$ Zob. H. Hinz, Dwie wizje dziejów Polski, Warszawa 1966, s. 5-6.

${ }^{44}$ Zob. szerzej: M. Kęsek, Wizerunek Kościoła Katolickiego w Polsce...

${ }_{45}$ Zob. E. Szmigielska, Frycz Modrzewski, czyli o odwadze mądrości, s. 4.

${ }^{46}$ Zob. T. Mitek, Interpretacje światopoglądowe. Ekumenizm, „Żołnierz Wolności” 38 (1987) nr 284, s. 4 .

47 Zob. W. Bortnowski, W 3oo. rocznicę powstania Kostki-Napierskiego, „Żołnierz Wolności” $2(1951) \mathrm{nr} 166$, s. 2. 
teoretycznego i politycznego KC PZPR „Nowe Drogi”, uznał powstanie Kostki-Napierskiego za ruch postępowy ${ }^{48}$.

Nic więc dziwnego, że postać biskupa w kontekście nowej sytuacji społeczno-politycznej, w której to chłopi otrzymali na własność ziemię, jawiła się jako ucieleśnienie przeciwnika wolności i postępu. Stąd też była nieustannie przywoływana na łamach różnorodnych czasopism. Widać to w 1952 roku, kiedy to Kazimierz Jankowski, recenzując na łamach „Żołnierza Wolności” sztukę teatralną Kazimierza Korcellego Stefan Czarnecki i jego żołnierze, wystawioną w Teatrze Domu Wojska Polskiego w Warszawie, wskazał na budzące odrazę cyniczne postępowanie biskupa, które swą grą ukazał aktor Mieczysław Pawlikowski ${ }^{49}$.

Postacią ze wszech miar negatywną z punktu widzenia propagandy był biskup inflancki Józef Kossakowski (1738-1794), którego osoba, jako biskupa zdrajcy, została w 1950 roku zakwalifikowana przez Wydział Propagandy KC PZPR jako przydatna dla agitacji antykościelnej wśród różnych środowisk $^{50}$. Postać biskupa Kossakowskiego jako zdrajcy znalazła się także w wydawnictwach Zespołu Propagandowo-Szkoleniowego Centralnego Komitetu Stronnictwa Demokratycznego ${ }^{51}$ oraz w broszurce propagandowej wydanej w tymże roku przez Związek Młodzieży Wiejskiej i Towarzystwo Szkoły Świeckiej ${ }^{22}$. To samo stwierdzenie znalazło się w przemówieniu Zenona Kliszki, członka Biura Politycznego KC PZPR, a zarazem przewodniczącego Komisji Ideologicznej, wygłoszonym w niemieckim obozie zagłady w Sztutowie podczas manifestacji zorganizowanej w celu potępienia Orędzia biskupów polskich do niemieckich. We wspomnianym przemówieniu Kliszko, mając na myśli biskupów polskich, którzy podpisali się pod wydanym Orędziem, określił bp. Kossakowskiego jako targowiczanina działającego na szkodę państwa i narodu ${ }^{53}$.

${ }^{48}$ Zob. J. Bardach, W 3oo. rocznice powstania chłopskiego pod wodza Kostki-Napierskiego, „Nowe Drogi” 3 (1951), s. 91.

49 Zob. K. Jankowski, Sztuka o Stefanie Czarnieckim, „Żołnierz Wolności” 3 (1952) nr 299, s. 4 .

${ }^{50}$ Zob. Polska Ludowa a Kościót katolicki, s. 108.

${ }^{51}$ Zob. S. Idzior, Państwo a Kościót, s. 40, 42.

${ }^{52}$ Zob. S. Dzierżak, Pamiętamy - nie przebaczamy. Wielka manifestacja w Oświęcimiu-Brzezince i Sztutowie, „Żołnierz Wolności” 17 (1966) nr 95, s. 1, 5; C. Kryczek, Polskie Tysiąclecie a kościelne Millenium, Wrocław 1966, s. 11.

${ }_{53}$ Zob. S. Dzierżak, Pamiętamy..., s. 1-5. 
W 1959 roku informowano o tym biskupie w biuletynie przeznaczonym do użytku wewnętrznego dla kadry $\mathrm{WP}^{54}$. Natomiast w 1966 roku w tejże gazecie określono tego biskupa jako „zdrajcę na obcym żołdzie”, jednego z tych, którzy przyłożyli rękę do drugiego rozbioru Polski ${ }^{55}$. W 1971 roku ponownie informowano o nim w materiałach do szkolenia ideologicznego, wydanych przez Zarząd Propagandy i Agitacji Głównego Zarządu Politycznego wP, a w 1988 roku w Zarysie religioznawstwa ${ }^{56}$. W 1985 roku ponownie sylwetka biskupa, po prawie 2o-letnim milczeniu, znalazła się na łamach „Żołnierza Wolności”, dla poparcia wysuwanej przez propagandzistów tezy o patriotycznym niższym duchowieństwie i zdradzieckim episkopacie ${ }^{57}$.

Postacią pokroju biskupa J. Kossakowskiego był także według propagandy biskup wileński Ignacy Massalski (1726-1794), powieszony bez sądu przez lud Warszawy w 1794 roku $^{58}$. Przytaczając opinie na jego temat w 1951 roku na łamach „Żołnierza Wolności”, informowano, że biskup wraz z innymi dygnitarzami „rozdrapywał dobra” zlikwidowanego majątku jezuitów, które miały być przeznaczone na fundusz komisji Edukacji Narodowej ${ }^{59}$. W 1966 roku postać biskupa, w kontekście prowadzonej propagandy potępienia autorów Orędzia biskupów polskich do niemieckich, została ponownie przypomniana na łamach „Żołnierza Wolności”, jako będącego na obcym żołdzie zdrajcy narodu i państwa, który przyłożył rękę do drugiego rozbioru Polski, za co podczas insurekcji kościuszkowskiej poniósł zasłużoną karę ${ }^{60}$. Także w roku 1971 postać tego biskupa służyła jako temat przydatny dla celów szkolenia ideologicznego w wojsku - w materiałach szkoleniowych wydanych przez Zarząd Propagandy i Agitacji Głównego Zarządu Politycznego wP ${ }^{61}$.

${ }^{54}$ Zob. A. Nowicki, Ateizm w Polsce i jego aktualne potrzeby, „Biuletyn Informacyjny” (Wyd. Zarząd Propagandy i Agitacji GzP) 1959 nr 16, s. 11.

${ }_{55}$ Zob. S.Z., Co to znaczy „nie tylko w świątyni”, „Żołnierz Wolności” 17 (1966) nr 43, s. 2.

${ }_{56}$ Zob. Wybrane zagadnienia światopoglądowe, Warszawa 1971, s. 47; J. Czerwiński, Kościót katolicki w dziejach Polski, w: Zarys religioznawstwa, red. J. Keller, Warszawa 1988, s. 450.

57 Zob. J. Żuraw, Nasze konsultacje. Kościół a powstania narodowe, „Żołnierz Wolności” $36(1985) \mathrm{nr} 56$, s. 4.

${ }^{58}$ I. Szybiak, Massalski Ignacy Jakub h. własnego (1726-1794) biskup wileński działacz polityczny prezes Komisji Edukacji Narodowej, w: Polski słownik biograficzny, t. 20, Kraków 1975, s. 138 .

59 Zob. W. Bortnowski, Trzeba nam ludzi zrobić obywatelami. (W rocznicę powstania Komisji Edukacji Narodowej 1773-1951), „Żołnierz Wolności” 2 (1951) nr 273, s. 4.

${ }^{60}$ Zob. S.Z., Co to znaczy „nie tylko $w$ świątyni”..., s. 2.

${ }^{61}$ Zob. Wybrane zagadnienia światopoglądowe, s. 47. 
Częściowo wiadomości propagandy PRL na temat biskupa Massalskiego są zgodne z opracowaniami naukowymi. Stwierdzono bowiem, że w roku 1777 Józef Wybicki wizytujący z ramienia Komisji Edukacji Narodowej część szkół na Litwie i sprawdzający stan kasy funduszu edukacyjnego, udowodnił biskupowi Massalskiemu znaczne nadużycia finansowe ${ }^{62}$.

\section{Podsumowanie}

Władze PRL, dążąc do likwidacji Kościoła, prowadziły z nim walkę na różnych polach, w tym także w sferze ideologicznej. Jej celem było przekształcenie światopoglądu społeczeństwa PRL w kierunku marksistowsko-leninowskim. Miało to być społeczeństwo wolne od fideizmu, wyznające światopogląd materialistyczny. We wrześniu 1951 roku w Moskwie miała miejsce wizyta urzędników PZPR zajmujących się propagandą. Od tego czasu redakcje gazet i czasopism w Polsce miały pracować na wzór radzieckich, czyli ściśle wykonywać polecenia Wydziału Propagandy Kc zgodnie z aktualną linią polityczną ${ }^{63}$. Publicysta, który nie przestrzegał tej reguły, był zagrożony nawet karą więzienia ${ }^{64}$. Aby zrealizować nakreślony cel, rządzący posługiwali się wieloma nieprawdziwymi artykułami, które - publikowane w prasie - przybierały formę propagandy. Propaganda antykościelna przeciwko Kościołowi prezentowana na łamach wielu czasopism była klasyczną propagandą wertykalną, którą cechuje przepływ informacji i przekazów treści od wierzchołka struktury do dołu i która opiera się na środkach masowej informacji. Jest ona typowa dla ustrojów totalitarnych ${ }^{65}$. Najbardziej przykrym następstwem było nie tylko oczernianie i dyskredytacja

${ }^{62}$ Zob. I. Szybiak, Massalski Ignacy Jakub h.własnego..., s. 137; B. Kumor, Historia Kościoła, t. 6: Czasy nowożytne. Kościót w okresie absolutyzmu i Oświecenia, Lublin 2005, s. 213, s. 216218; R. Butterwick, Polska rewolucja a Kościół katolicki 1788-1792, tłum. M. Ungiewski, Kraków 2012, s. 190; R. Butterwick-Pawlikowski, Before and after suppression. Jesuits and former Jesuits in the Polish-Lithuanian Commonwealth, c. 1750-1795, w: Jesuit survival and restoration. A global history 1773-1900, eds. R. A. Maryks, J. Wright, Leiden-Boston 2014, s. 60-61; J. Kamińska, Akademia Wileńska 1773-1780, „Rozprawy z Dziejów Oświaty” 38 (1997), s. 65-66.

${ }_{33}$ Zob. M. Kęsek, Wizerunek Kościoła Katolickiego w Polsce..., s. 5.

${ }^{64}$ Zob. T. Goban-Klas, Niepokorna orkiestra medialna. Dyrygenci i wykonawcy polityki informacyjnej w Polsce po 1944 r., Warszawa 2004, s. 109-110, 171-172.

${ }_{65}$ Zob. B. Dąbek-Ostrowska, J. Fras, B. Ociepka, Teoria i praktyka propagandy, Wrocław 1999, s. 38 . 
wielu osób, ale i to, że historię potraktowano jako narzędzie manipulacji i podporządkowano ją celom ówczesnej propagandy.

\section{Bibliografia}

Dąbek-Ostrowska B., Fras J., Ociepka B., Teoria i praktyka propagandy, Wrocław 1999.

Dowiat J., Historia Kościoła katolickiego w Polsce (do połowy xV w.), Warszawa 1968.

Dudek A., Gryz R., Komuniści i Kościół w Polsce (1945-1989), Kraków 2006.

Fijałkowska B., Partia wobec religii i Kościoła w PRL, t. 2, cz. 2, Olsztyn 2000.

Goban-Klas T., Niepokorna orkiestra medialna. Dyrygenci i wykonawcy polityki informacyjnej $w$ Polsce po 1944 r., Warszawa 2004.

Hinz H., Dwie wizje dziejów Polski, Warszawa 1966.

Historyczne tło i aktualny stan stosunków między państwem a Kościołem, Warszawa 1984.

Idzior S., Państwo a Kościót, Warszawa 1952.

Kęsek M., Wizerunek Kościoła Katolickiego w Polsce do 1945 r. na łamach „Żołnierza Wolności" w latach 1950-199o, Kraków 2008, mps.

Konopczyński W., Dzieje Polski nowożytnej, t. 1-2, Warszawa 1986.

Kot S., Andrzej Frycz Modrzewski. Studium z dziejów kultury polskiej w XVI w., Kraków 1919.

Królik S., Laicyzacja życia społecznego w Polsce, w: Społeczeństwo - kultura - technika. Materiały nr 5 dla kierowników grup do zajęć politycznych z elewami szkót podoficerskich, żołnierzami i podoficerami stużby zasadniczej, Warszawa 1968.

Ładosz J., Kozyr-Kowalski S., Dialektyka a społeczeństwo, Warszawa 1972.

Ładosz J., Materializm dialektyczny, Warszawa 1973.

Łukaszewicz W., Targowica i powstanie kościuszkowskie. Ze studiów nad historiq Polski XVIII w., Warszawa 1953.

Marek Ł., Bortlik-Dźwierzyńska M., Za Marksem bez Boga. Laicyzacja życia społecznego w Polsce w latach 1945-1989, Katowice 2014.

Mazur M., Propagandowy obraz świata. Polityczne kampanie prasowe w PRL 19561980. Model analityczno-koncepcyjny, Warszawa 2003.

Noszczak B., Polityka państwa wobec Kościoła rzymskokatolickiego w Polsce w okresie internowania prymasa Stefana Wyszyńskiego 1953-1956, Warszawa 2008.

Nowicki A., 1000 lat zatargów z papieżami, Warszawa 1950. 
Nowicki A., Ateizm w Polsce i jego aktualne potrzeby, „Biuletyn Informacyjny” (Wyd. Zarząd Propagandy i Agitacji GzP) 1959 nr 16.

Nowicki A., Grzegorz z Sanoka 1406-1477, Warszawa 1958.

Nowicki A., Papieże przeciw Polsce, Warszawa 1949.

Przez Morze Czerwone. Kościół w Polsce pod rządami komunistów. Propaganda antykościelna. Dodatek specjalny do „Gościa Niedzielnego” pod red. A. Dziurok, A. Grajewski, Warszawa 2009.

Tło i aktualny stan stosunków między państwem a Kościołem, Warszawa 1984.

Wybrane zagadnienia światopoglądowe, Warszawa 1971.

Zagadnienia światopoglądowe. Materiały nr 3 do szkolenia politycznego podoficerów zawodowych, Warszawa 1961.

Zarębski I., Grzegorz z Sanoka (ok. 1407-1477) arcybiskup lwowski, prozaik i poeta, Kraków 1960.

Żaryn J., Kościół a władza w Polsce (1945-1950), Warszawa 1997.

Żaryn J., Kościół w PRL, Warszawa 2004.

„Żołnierz Wolności” wybrane numery z lat 1951-1987.

\section{Streszczenie}

Jednym z podstawowych ideologicznych celów przejmujących władzę komunistów w Polsce po zakończeniu II była walka z religią. Cel ten wynikał z przyjętej ideologii marksistowsko-leninowskiej (opartej na materializmie dialektycznym i historycznym) odrzucającej istnienie Boga. Nic więc dziwnego, że ówczesne władze polityczne na powyższej podbudowie ideologicznej wobec powszechnie występującej religijności społeczeństwa traktowały Kościół jako konkurenta, który mógłby osłabić jej autorytet. Z tego powodu władze Polskiej Rzeczypospolitej Ludowej (PRL) w latach 1944-1989 z różnym nasileniem stosowały wobec Kościoła politykę represji i deprecjonowania. Istotnym elementem prowadzonej polityki stała się antykościelna propaganda obejmująca różnorodne aspekty życia i funkcjonowania Kościoła.

W niniejszym artykule zwrócono uwagę na propagandę polityczną PRL, a konkretnie próbowano ukazać, $w$ jakim świetle ta propaganda przedstawiała poszczególnych biskupów z czasów staropolskich, ukazując przy tym, w oparciu o poszczególne przykłady, manipulację, kłamstwa, brak rzetelności i obiektywizmu ówczesnej propagandy. 


\section{Słowa kluczowe}

Polska Rzeczpospolita Ludowa (PRL), propaganda, biskupi, Kościół rzymskokatolicki, walka $\mathrm{z}$ religią

\section{Summary}

\section{Bishops of Polish old times in the light of anti-church propaganda led by political authorities of the People's Republic of Poland in years 1944-1989}

One of the fundamental ideological goals of communists coming into power in Poland after the end of the World War II was the fight against religion. The goal resulted in the marxist-leninist ideology (based on dialectical and historical materialism) which rejected the existence of God. No wonder that the contemporaneous political authorities supported by the ideology mentioned above towards wide spread devotion of the society treated the Church as the opponent which can make them less powerful. Hence, the People's Republic of Poland (PRP) authorities used in a different intensity the policy of repression and condemnation against the Church in years 1944-1989. Anti-church propaganda became the crucial element of the government's policy. The propaganda covered various aspects of life and functioning of the Church.

The present article highlights the political propaganda of the PRP and what was carefully underlined was the fact how the propaganda presented particular bishops from old Polish times showing at the same time, based on certain examples, manipulation, lies, and lack of reliability and objectivity of the contemporaneous propaganda.

\section{Keywords}

People's Republic of Poland (PRP), propaganda, bishops, Roman-Catholic Church, fight against religion 